\title{
Allometric Study of the Postnatal Development of the Rat Sublingual Glands
}

\author{
By \\ Renato MASSAHARU HASSUNUMA ${ }^{1}$ and Rumio TAGA ${ }^{2,3}$ \\ ${ }^{2}$ Laboratory of Histology, Department of Morphology, Faculty of Dentistry of Bauru, USP, Brazil \\ - Received for Publication, October 25, $1996-$
}

Key Words: Sublingual glands, Development, Allometry, Morphometry

\begin{abstract}
Summary: The authors studied the rat sublingual glands growth in the period of 2 to $\mathbf{4 0}$ days of the postnatal life. The allometric coefficients for the gland mass growth and morphometrically evaluated volume of different gland components in relation to body mass growth, and for the parenchymal volume growth in relation to stroma volume growth, were calculated by the Wald non parametric method, modified by Bartlett. The allometric analysis showed that the gland mass, the mucous cells volume, the serous cells volume, the duct volume and the stroma volume exhibited statistically significant allometric growths with monophasic pattern and allometric coefficient of $0.93,1.11,0.76,0.86$ and 1.00 , respectively. The analysis of the confidence intervals for these various $k$ values, permitted to conclude that the differential growth of the gland mass is isometric, of the mucous cells volume is positive, of the serous cells and duct are negative and of the stroma volume is isometric.
\end{abstract}

The morphological differentiation of the various adenomer components of rat sublingual glands occurs in the intra-uterine life (Ball, 1974). Thus, at birth the acini, intercalated ducts and striated ducts are present in the glandular lobules, but are yet morphologically immatures (Leeson \& Both, 1961).

During first four weeks of the post-partum, the mucous and serous cells from acini undergo evident maturation, characterized by increase in cell volume and accumulation of secretory materials and membranes from rough endoplasmic reticulum and Golgi complex (Leeson \& Both, 1961; Taga, 1976). Concomitantly, in this same period, occurs intense proliferative activity in all morphological compartments of the sublingual glands (Taga, 1976). This increment on the cell volume and absolute number of cells promotes an increase of $1076 \%$ on the fresh mass from the glands (Taga, 1976; Taga \& Sesso, 1978).

Various events which occur during this conspicuous glandular growth were already analyzed by morphometric, biochemical, radioautographic and ultrastructural studies (Leeson \& Both, 1961; Taga, 1976; Taga \& Sesso, 1978). However, does not exist an allometric study about the postnatal development of the rat sublingual glands. Thus, in the present investigation, we decided to study the allometric growth of gland mass and volume from each glandular morphologic component in relation to body mass growth and between the parenchymal volume growth in relation to stroma volume growth, with the objective of determining growth parameters between the parts or between the parts and the whole, in this system subject to pondered or volumetric changes.

\section{Material And Methods}

\section{General Procedures}

The present investigation was conducted in albino Wistar rats (Rattus norvegicus) of both sexes, created and maintained on the Central Animal House of Dental School of Bauru, University of São Paulo, Brazil.

Groups of $20,15,10,10,8,4$ and 4 rats each aged, respectively, 2, 5, 10, 15, 20, 30 and 40 days of postnatal life, were used to allometric analysis. All glands were collected between 10:00 and 12:00 AM.

The rats for each age, were anesthetized by in-

\footnotetext{
${ }^{1}$ Recipient of FAPESP fellowship Proc. 94/1109-3

${ }^{3} \mathrm{CNPq}$ Research fellow

Correspondence to: Dr. Rumio Taga, Faculdade de Odontologia de Bauru - USP. A1. Octávio Pinheiro Brizolla, 9-75, CP 73 - CEP 17043-101, Bauru, SP, Brasil.
} 
halation of ethyl ether and the body mass from each animal, was weighted with a METTLER P1000 scale. The sublingual glands from each animal were carefully dissected and rapidly removed, and the fresh mass of the two glands was then weighted using a METTLER P20 precision scale.

The fresh gland volume was calculated by the following equation: $\mathrm{Vgl}=\mathrm{m} / \mathrm{d}$, where, $\mathrm{m}=$ fresh gland mass and $d=$ gland density. The value $d=$ $1.09 \mathrm{~g} / \mathrm{cm}^{3}$ were used. This value of density was obtained by Pardini, Achôa and Taga (1993) for the rat submandibular gland.

\section{Histological Procedures for Morphometric Study}

Sublingual glands of five animals for each aged group, were fixed in Bouin liquid (picro-aceticformalin solution) for 3 hours and maintained in $70 \%$ ethanol solution overnight. In the following day, the glands were submitted to routine standardized processing by dehydration in crescent solutions of ethanol, clearing in xylene and paraffin embedding. Semiserial $5 \mu \mathrm{m}$ thick sections of the glands from each animal were obtained with Leica-Jung Multicut microtome and stained with hematoxylin and eosin.

Morphometric Evaluation of the Volume Density (Vvi) of the Different Glandular Components

The volume densities of the mucous and serous acinar cells, ducts and stroma from the glands were obtained using a Zeiss II integration grid containing 100 points and 10 parallel lines placed on a Zeiss kpl $8 \times$ eyepiece. Counts were performed on Zeiss microscope with $100 \times$ oil immersion objective. On 50 histological fields selected in the sections of the glands from each animal by systematic randomization (Weibel, 1969), we counted the number of points falling on the glandular component $(\mathrm{Pi})$ and on the gland $(\mathrm{Pt})$. The volume density from each glandular component was calculated by the following relation: $\mathrm{Vvi}=\mathrm{Pi} / \mathrm{Pt}$ (in $\mu \mathrm{m}^{\circ}$ ) (Weibel, 1969).

\section{Calculation of Total Volume from Each Glandular Component}

Knowing the postnatal evolution of the mean volume density from each glandular component, we calculated for glands from each animal used in allometric study, the total volume (Vti) from each glandular component (i), by the following equation: $\mathrm{Vti}=\mathrm{Vvi} . \mathrm{Vgl}$, where $\mathrm{Vvi}=$ mean volume density from gland component and $\mathrm{Vgl}=$ gland volume from each animal.

\section{Allometric Analysis}

We studied the allometric relation between the growth of: a) gland mass and body mass; b) volume of mucous acinar cells and body mass; c) volume of serous acinar cells and body mass; d) volume of ducts and body mass; e) stroma volume and body mass; and f) parenchyma volume and stroma volume.

The allometric relation between two ponderal or volumetric parameters in a system subject to modifications is represented by the coefficient $(k)$ from equation type $y=b \cdot x^{k}$ or $\log y=\log b+k \cdot \log x$ (Huxley, 1924).

On the present investigation, we calculated the coefficient of allometry (k) by the Wald nonparametric method (1940) modified by Bartlett (1949), using a program which we developed to an IBM-PC 386 - microcomputer.

In this method, the logarithms of the data are divided in three successive groups exhibiting approximately same number of values. The division is based on the variable of small variation. The coefficient (k) of the equation is calculated by the relation: $k=y_{3}-y_{1} / x_{3}-x_{1}$, where $y_{i}$ and $x_{i}$ are the means of extreme groups. The limits of confidence interval of $\mathrm{k}$ and the value of $\mathrm{t}$ for the test of linearity are also estimated by computer program.

\section{Results}

\section{Ponderal and Morphometric Results}

The evolution of body mass, gland mass, gland volume, volume density and absolute volume from each glandular component are shown in Table 1.

The analysis of the results of Table 1 indicated that the body mass exhibited a continuous increase of $1,297 \%(p<0.01)$ during 2 to 40 days of postnatal life. The highest velocity of growth was observed between 20 and 30 days, when the body mass showed a mean daily increase of $4.2 \mathrm{~g} /$ day.

The gland mass had a markedly gain of $600 \%$ between 5 and 30 days of postnatal life $(p<0.01)$. During 5 to 10,10 to 15 and 15 to 30 days the growths were of $69.8 \%(\mathrm{p}<0.01), 29.9 \%(\mathrm{p}<0.05)$ and $217.3 \%(\mathrm{p}<0.01)$, respectively. The greatest growth period of gland mass occurred between 15 and 30 days, when the mean daily increase was of $2.0 \mathrm{mg} /$ day. Among 2 to 5 , and 30 to 40 days was not observed statistically significant increment of gland mass $(p>0.05)$.

Thereby the absolute gland volume also increased $1,017 \%(\mathrm{p}<0.01)$ continuously during the period of 2 to 30 days. Between the $30^{\text {th }}$ day to $40^{\text {th }}$ day wasn't observed statistically significant increase $(p>0.05)$.

In regard to evolution of the compartmental volume from each glandular component - mucous acinar cells, serous acinar cells, ducts and stroma the following comments are presented:

- the absolute volume of mucous acinar cells exhibited a conspicuous increase of $1,761 \%(p<0.01)$ 
Table 1. Evolution of body mass, gland mass, volume density and total volume of the sublingual gland and each glandular component in the first $\mathbf{4 0}$ days of postnatal life

\begin{tabular}{|c|c|c|c|c|c|c|c|}
\hline Age & 2 & 5 & 10 & 15 & 20 & 30 & 40 \\
\hline $\begin{array}{l}\text { Body mass in } \\
\mathrm{g} \pm \text { SEM }\end{array}$ & $6.5 \pm 0.39$ & $10.2 \pm 0.80$ & $17.5 \pm 0.62$ & $22.1 \pm 0.86$ & $32.0 \pm 1.90$ & $74.4 \pm 2.11$ & $90.8 \pm 3.78$ \\
\hline $\begin{array}{l}\text { Gland mass } \\
\text { in mg } \pm \text { SEM } \\
\text { Volume densit }\end{array}$ & $\begin{array}{l}4.6 \pm 0.35 \\
\text { in \% }\end{array}$ & $6.3 \pm 0.54$ & $10.7 \pm 0.45$ & $13.9 \pm 0.95$ & $22.6 \pm 2.33$ & $44.1 \pm 1.60$ & $51.6 \pm 2.53$ \\
\hline Mucous cells & $38.8 \pm 2.20$ & $41.3 \pm 2.10$ & $50.8 \pm 1.24$ & $53.6 \pm 1.61$ & $52.3 \pm 1.11$ & $53.5 \pm 2.40$ & $64.8 \pm 1.20$ \\
\hline Serous cells & $23.4 \pm 2.02$ & $29.5 \pm 2.62$ & $17.9 \pm 0.51$ & $18.8 \pm 1.22$ & $21.3 \pm 1.14$ & $18.3 \pm 1.13$ & $11.6 \pm 1.39$ \\
\hline Duct & $9.3 \pm 0.63$ & $9.0 \pm 0.91$ & $11.0 \pm 0.63$ & $9.3 \pm 1.65$ & $7.3 \pm 0.93$ & $7.4 \pm 2.11$ & $6.3 \pm 1.03$ \\
\hline Stroma & $28.5 \pm 0.92$ & $20.2 \pm 0.60$ & $20.2 \pm 0.99$ & $18.2 \pm 0.77$ & $19.0 \pm 1.73$ & $20.8 \pm 1.95$ & $17.2 \pm 1.25$ \\
\hline \multicolumn{8}{|c|}{ Total volume in $\mathrm{mm}^{3}$} \\
\hline $\begin{array}{l}\text { Sublingual } \\
\text { gland }\end{array}$ & $4.2 \pm 0.13$ & $5.7 \pm 0.21$ & $9.8 \pm 0.21$ & $12.7 \pm 0.50$ & $20.8 \pm 1.70$ & $40.5 \pm 1.10$ & $47.4 \pm 2.60$ \\
\hline Mucous cells & $1.7 \pm 0.05$ & $2.4 \pm 0.09$ & $5.0 \pm 0.10$ & $6.8 \pm 0.27$ & $10.9 \pm 0.89$ & $21.7 \pm 0.59$ & $30.7 \pm 1.68$ \\
\hline Serous cells & $1.0 \pm 0.03$ & $1.7 \pm 0.06$ & $1.8 \pm 0.04$ & $2.4 \pm 0.09$ & $4.4 \pm 0.36$ & $7.4 \pm 0.20$ & $5.5 \pm 0.30$ \\
\hline Duct & $0.4 \pm 0.01$ & $0.5 \pm 0.02$ & $1.1 \pm 0.02$ & $1.2 \pm 0.05$ & $1.5 \pm 0.12$ & $3.0 \pm 0.08$ & $3.0 \pm 0.16$ \\
\hline Stroma & $1.2 \pm 0.03$ & $1.2 \pm 0.04$ & $2.0 \pm 0.04$ & $2.3 \pm 0.09$ & $4.0 \pm 0.32$ & $8.4 \pm 0.23$ & $8.2 \pm 0.45$ \\
\hline
\end{tabular}

in whole period studied;

- the compartmental volume of serous cells augmented $70 \%(\mathrm{p}<0.01)$ and $320 \%(\mathrm{p}<0.01)$, respectively, for the periods of 2 to 5 and 10 to 30 days. Between the $5^{\text {th }}$ and $10^{\text {th }}$ day there was no significant variation $(p<0.05)$, while that between the $30^{\text {th }}$ to $40^{\text {th }}$ day we detected a $34 \%$ reduction $(\mathrm{p}<0.01)$;

- the ductal volume increased $177 \%(\mathrm{p}<0.01)$ and $97 \%(\mathrm{p}<0.01)$, between 2 to 10 and 20 to 30 days, respectively;

- and the stroma volume grew $264 \%(\mathrm{p}<0.01)$ in the period of 15 to 30 days and in others periods, didn't exhibit statistically significant differences among the values.

\section{Allometric Results}

The results of allometric analysis of the various dimensions are shown in Table 2 and in Figures 1a, $b, c, d$, e and $f$.

In the present research, we intended to study the allometric relation between the glandular mass and body mass growth. For this purpose, before starting the calculations, we placed in Figure 1a, the decimals logarithms of gland mass and body mass in class intervals of 0.1 . The analysis of distribution of the points in the graphic is very important to verify if the growth is monophasic or multiphasic. In actual case, the distribution of the points indicated the occurrence of only one phase in allometric growth of the gland in the period of $\mathbf{2}$ to $\mathbf{4 0}$ days of postnatal life.

The value of obtained allometric coefficient (k), such as the value of " $t$ " and the limits of confidence

Table 2. Results of allometric analysis of various parameters in the first 40 days of postnatal life

\begin{tabular}{|c|c|c|c|c|}
\hline Parameters & Period & Value of $K$ & $\begin{array}{l}\text { Limits of Confidence } \\
\text { Interval }\end{array}$ & Value of " $t$ " \\
\hline $\begin{array}{l}\text { gland mass } \\
\mathrm{x} \text { body mass }\end{array}$ & 2 to 40 days & 0.93 & $\begin{array}{l}S=1.06 \\
I=0.80\end{array}$ & 1.67 \\
\hline $\begin{array}{l}\text { volume of mucous cells } \\
\mathrm{x} \text { body mass }\end{array}$ & 2 to 40 days & 1.11 & $\begin{array}{l}S=1.14 \\
I=1.09\end{array}$ & 1.06 \\
\hline $\begin{array}{l}\text { volume of serous cells } \\
\mathrm{x} \text { body mass }\end{array}$ & 2 to 40 days & 0.76 & $\begin{array}{l}S=0.77 \\
I=0.75\end{array}$ & 0.28 \\
\hline $\begin{array}{l}\text { volume of ducts cells } \\
\mathrm{x} \text { body mass }\end{array}$ & 2 to 40 days & 0.86 & $\begin{array}{l}\mathrm{S}=0.88 \\
\mathrm{I}=0.84\end{array}$ & 0.78 \\
\hline $\begin{array}{l}\text { volume of stroma cells } \\
\mathrm{x} \text { body mass }\end{array}$ & 2 to 40 days & 1.00 & $\begin{array}{l}S=1.03 \\
I=0.98\end{array}$ & 0.90 \\
\hline $\begin{array}{l}\text { volume of parenchyma } \\
\mathrm{x} \text { volume of stroma }\end{array}$ & 2 to 40 days & 1.21 & $\begin{array}{l}S=1.22 \\
I=1.21\end{array}$ & 0.20 \\
\hline
\end{tabular}


interval of $\mathrm{k}$ are shown in Table 2.

After the computation of these values, the points necessary to trace the straight line were determined (Figure 1a).

The obtained coefficient $k$ was 0.93 and because the value of calculated " $t$ " was smaller than the $t_{\text {critic }}=1.98$, the hypothesis of the gland mass and of body mass logarithms to be associated by a straight line can't be rejected, and so, there is allometric relation between the growth of gland mass and of body mass.

This proceeding was repeated for the others examined parameters, obtaining for all monophasic growths with statistically significant allometric coefficients $\mathbf{k}$. Therefore, the obtained values are presented in Table 2 and in the respective Figures.

\section{Discussion}

Soon after birth, the sublingual glands of albino rat exhibit well-defined acini, intercalated ducts, striated ducts and excretory ducts, but still immature (Leeson and Both, 1961).

In the first month of postnatal life, these glands undergo a significant fresh mass increase, with an augment of $1,076 \%$, between the $2^{\text {nd }}$ and $30^{\text {th }}$ day (Taga, 1975; Taga and Sesso, 1979). The autoradiographic evaluation using tritiated thymidine revealed that this growth occurs by proliferative activity of each cell type from the developing glands (Taga, 1976; Taga, Martini and Sesso, 1994). The analysis of the evolution from absolute number of cells in the various glandular compartments evaluated by stereological methods indicated that the highest growths occur in the compartments of mucous acinar cells, stroma and serous demilune cells (Taga and Sesso, 1979).

The objective of the present investigation was to study the allometric relation of the development of gland mass and the volume from each gland compartment with the increase of body mass. With this purpose, we call attention that in a growing biological system, three situations of differential growth can occur: $\left(1^{\text {st }}\right)$ when $k=1$, the growth is isometric, i.e., the daily increment of $y$ is equal to that of $x ;\left(2^{\text {nd }}\right)$ when $k>1$, there is a positive growth, it means that the enlargements of $y$ are relatively higher than that of $\mathbf{x}$; and $\left(3^{\text {rd }}\right)$ when $\mathbf{k}<1$, the growth is negative, or that the gains of $y$ are relatively smaller than that of $x$.

The analysis of ponderal results indicates that the body mass as well as the gland mass exhibited significant increases during postnatal development. The body mass grew $1,297 \%$ in the period of 2 to 40 days, while the gland mass increased $600 \%$ between 5 to 30 days of age. When the logarithms of these two variables were submitted to allometric analysis, they showed a monophasic pattern of evolution, with an allometric coefficient $\mathrm{k}=\mathbf{0 . 9 3}$ and since the confidence interval of $\mathbf{k}$ included the value 1 , the differential growth of gland mass in function to body mass is isometric, i.e., between 2 to 40 days of the postpartum, the unitary increase of gland mass is equal to unitary increase of body mass.

For comparation, Sesso et al. (1965) investigated the growth of the rat pancreas in function of body weight using allometric relations and detected three stages of growth. In the first stage the animal ages were between 2 and 15 days from the postpartum and the coefficient of allometry was $\mathrm{k}=0.735$, i.e., the weight of the pancreas in this phase increases proportionally less than that of the body. In the second stage, encompassing the $15^{\text {th }}$ to the $30^{\text {th }}$ day, the allometric coefficient was $k=2.170$, which implies a more rapid growth of the mass of the pancreas relative to the body. In the third stage the coefficient was found to decrease again so that pancreas growth was similar to that of the first stage.

On the other hand, the guinea pig pancreas during postnatal development exhibited two distinct phases of gland mass growth in function from the body mass. The first phase, comprising a period between the $2^{\text {nd }}$ to the $14^{\text {th }}$ day of postnatal life exhibited a positive growth of $k=1.79$ and the second phase, comprising a period between the $14^{\text {th }}$ to the $140^{\text {th }}$ day of age showed a negative growth of $k=0.84$ (Assis and Taga - manuscript in preparation).

The postnatal evolution of the absolute volume morphometrically determined of the different gland compartments showed a statistically significant increases for all gland components. In the mucous cells compartment this enlargement occurred during the whole period studied, however, in others structures, this growth happened during one or two phases of the considered period.

The allometric analysis from those morphometric parameters in relation to body mass, exhibited for every gland components a statistically significant allometric growth with a monophasic pattern. The calculated allometric coefficients $\mathrm{k}$ were $1.11,0.76$, 0.86 and 1.00 , for absolute volume of mucous cells, serous demilune cells, ducts and stroma, respectively. The examination of confidence interval from different values of $\mathbf{k}$ showed that the differential growth of mucous cells is positive, while in relation to serous cells and ducts the growth is negative and concerning stroma it is isometric.

When the volume of all components from the gland parenchyma was analyzed in function to stroma evolution, we obtained a statistically significant positive pattern of allometric growth with $\mathrm{k}=1.21$, i.e. in the period of 2 to 40 days from postpartum, 
the parenchymal volume increases unitarily 1.21 folds the stroma volume. This relation can be observed morphologically in the light microscope as diminution of the intralobular connective tissue spaces in the trajectory of the gland maturation during its postnatal development.

Thereby, the results obtained in the present investigation showed that the huge increase of gland mass presents a statistically significant allometric relation regarding to body growth. The volume growth of each gland morphological compartment exhibited also a significant allometric relation in function to the body development.

\section{Acknowledgments}

The authors are indebted to Ms. Tania Mary Cestari for the technical assistance and Ms. Beonildes Teresinha Ruiz Correia for typing the manuscript. This research was supported by grants of FAPESP (Proc. 94/1109-3).

\section{Bibliographic References}

1) Ball WD. Development of rat salivary glands. III. Mesenchymal specificity in the morphogenesis of the embryonic submaxillary and sublingual glands of the rat. $\mathrm{J} \exp$ Zool 1974; 188:277-288.

2) Bartlett MS. Fitting a straight line when both variable are subject to error. Biometrics 1949; 5:207-212.

3) Huxley JS. Constant differential growth-ratios and their significance. Nature 1924; 114:895-896.

4) Leeson CR and Booth WG. Histological, histochemical and electron-microscopic observations on the post-natal development of the major sublingual gland of the rat. J Dent Res $1961 ; 40: 838-845$.

5) Lison L. Statisque appliquée a la biologie expérimentale. Gauthier \& Villars, Paris, 1958.

6) Pardini LC, Achôa AS and Taga R. Morphometric evaluation of the total length of the striated ducts in the rat submandibular glands. Rev bras Ciên morfol 1993; 10:93-97.

7) Redman RS and Sreebny LM. The prenatal phase of the morphosis of the rat parotid gland. Anat Rec 1970; 168:127-138.

8) Sesso A, Cruz AR and Arruda-Leite JB. La croissance du pancréas chez le rat pedant la vie post-natale. Acta anat 1965; 62:283-295.

9) Taga R. Evolução das populações celulares das glândulas parótida e sublingual do rato durante a vida pós-natal inicial avaliada por estudos morfométricos, bioquímicos, radioautográficos e ultraestruturais. Department of Histology and Embriology, Biomedical Institute, University of São Paulo (Doctoral Thesis). São Paulo, 1976.

10) Taga $R$ and Sesso $A$. Avaliação do número de células de órgãos pela dosagem bioquímica de DNA em homogeneizados e por contagem direta através de métodos morfométricos. Ciênc e Cult 1978; 30:1232-1236.

11) Taga R, Martini DS and Sesso A. Autoradiographic evaluation of the cell cycle parameters of the various cells categories of the parotid, submandibular and sublingual glands of the suckling rat. Okajimas Folia Anat Jpn 1994, 70:255-260.

12) Wald A. The fitting of straight lines if both variables are subject to error. Ann Math Stat 1940; 11:284-300.

13) Weibel ER. Stereological principles of morphometry in electron microscopic cytology. Int Rev Cytol 1969; 26:235302. 
Fig. 1. Allometric growth of rat sublingual glands during the first $\mathbf{4 0}$ days of postnatal life from: (a) gland mass in relation to body mass, (b) mucous cells volume in relation to body mass, (c) serous cells volume in relation to body mass, (d) ducts volume in relation to body mass, (e) stroma volume in relation to body mass, (f) parenchyma volume in relation to stroma volume. 
(a)

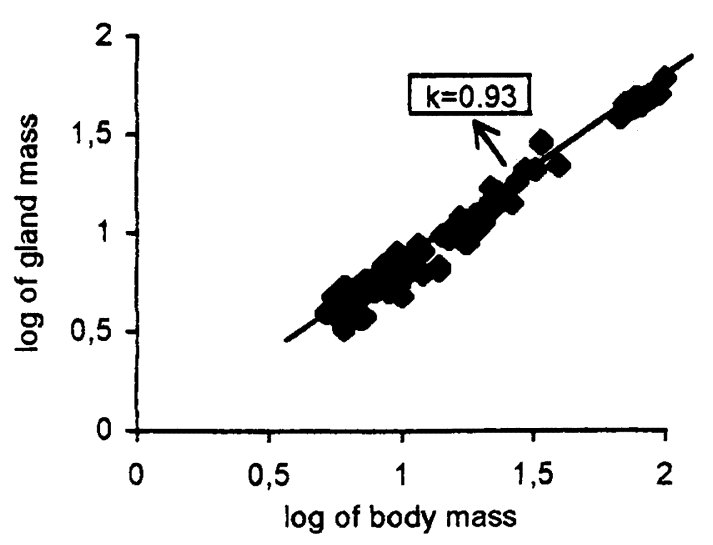

(b)

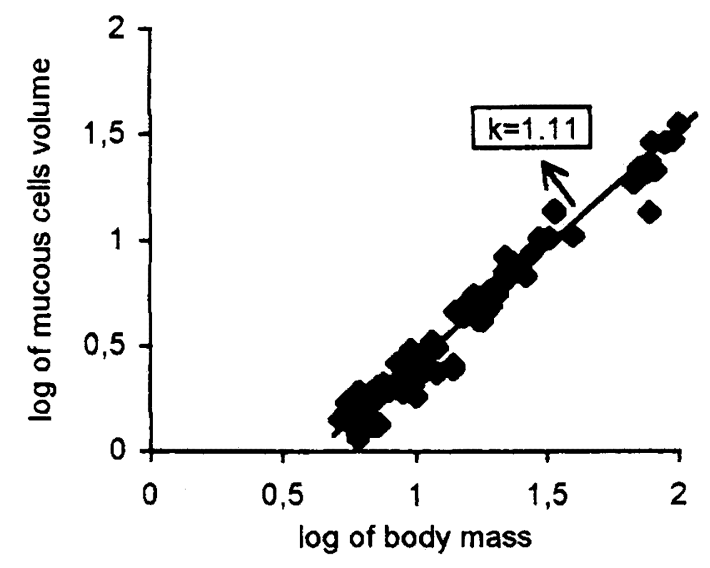

(c)

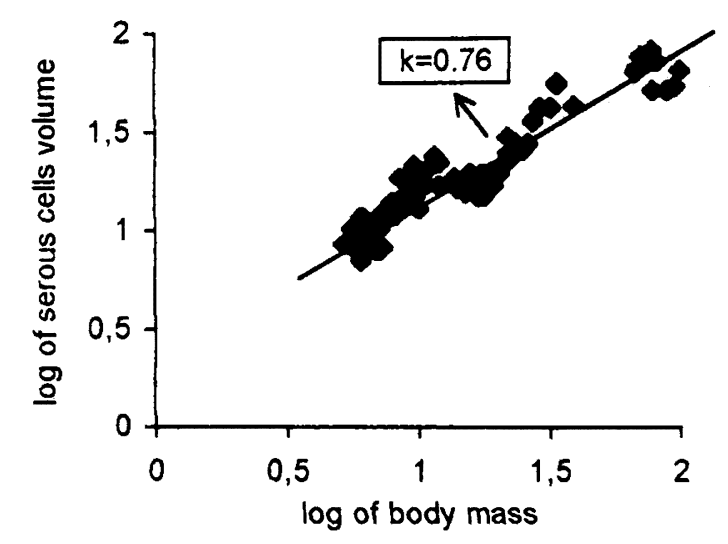

(d)

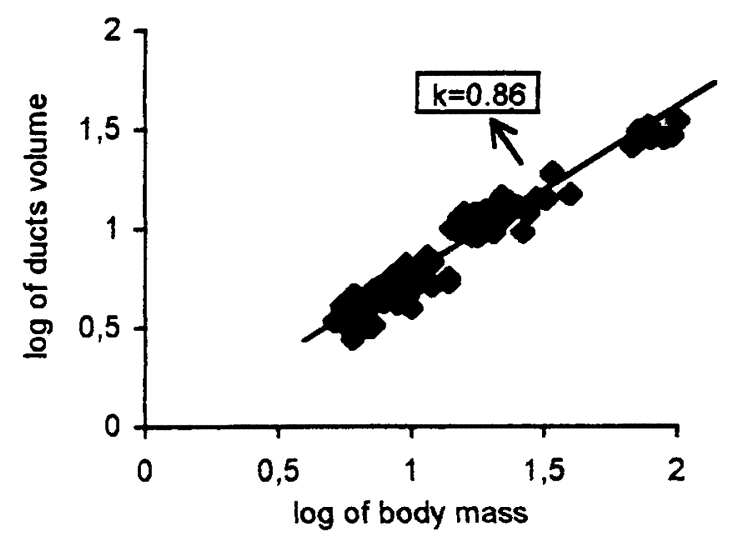

(e)

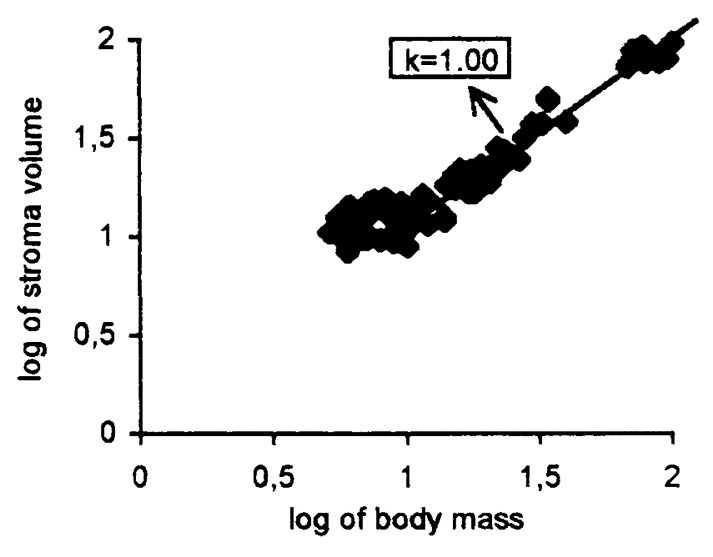

(f)

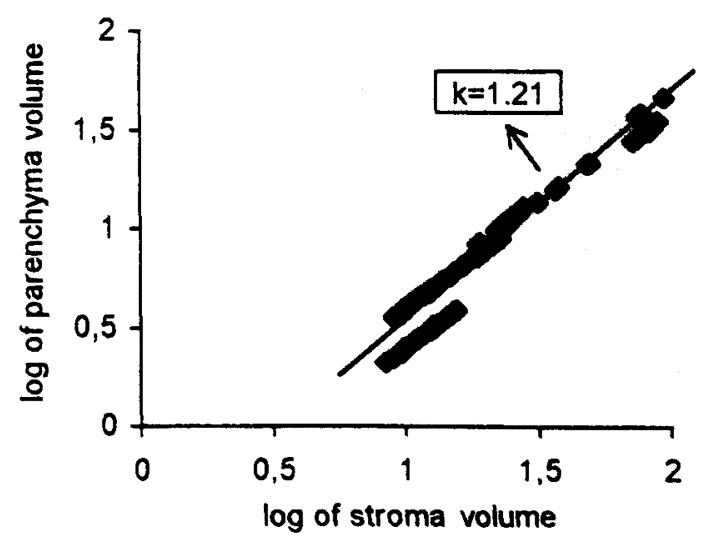

